\title{
Analysis of the Determinants of the Use of the Water Supply Service in the Republic of Congo: Case of the Commune of Pointe-Noire
}

\author{
Edouard Sukami, Hardy Zabatantou Louyindoula, Jacqueline Offele Okopoué \\ Faculty of Economics, Marien Ngouabi University, Brazzaville, Congo \\ Email: sukamiedouard@gmail.com
}

How to cite this paper: Sukami, E., Louyindoula, H. Z., \& Okopoué, J. O. (2021). Analysis of the Determinants of the Use of the Water Supply Service in the Republic of Congo: Case of the Commune of Pointe-Noire. Modern Economy, 12, 1913-1928.

https://doi.org/10.4236/me.2021.1212100

Received: November 4, 2021

Accepted: December 20, 2021

Published: December 23, 2021

Copyright $\odot 2021$ by author(s) and Scientific Research Publishing Inc. This work is licensed under the Creative Commons Attribution International License (CC BY 4.0). http://creativecommons.org/licenses/by/4.0/

\begin{abstract}
The objective of this article is to analyze the determinants that influence the behavior of Congolese households in the commune of Pointe-Noire in their choice of supply modes for running water. Using an unordered multinomial logit model, the study shows that only the variables household income, level of education, daily cost of purchasing water, gender, household size, type of construction materials and quantity of water drawn are significant determinants nts that positively influence the supply modes used for running water for the populations of the city of Pointe-Noire.
\end{abstract}

\section{Keywords}

Piped Water Supply, Determinant Analysis, Congo-Pointe-Noire

\section{Introduction}

The United Nations World Report 2021 shows that the supply of piped water worldwide needs improvement. At the Millennium Summit in 2000, 189 states made access to piped water one of the targets of the Millennium Development Goals (MDGs), which in 2015 became the Sustainable Development Goals (SDGs). According to the WHO/UNICEF (2019), 29\% of the world's population lacks access to safely managed piped domestic water services. In sub-Saharan Africa, $39 \%$ of the population lacks access to basic piped water services. In eastern and southern Africa, the proportion of people without access to water dropped from $59 \%$ in 2000 to $47 \%$ in 2015.

MICS (2014-2015) survey, which includes only the main sources of running 
water, indicates that in the commune of Pointe-Noire, $38 \%$ of households obtain their water from a connection to Congolese Waters (La Congolaise des Eaux) on their plot, $28 \%$ from a neighboring connection, and $28 \%$ from a well or borehole, while $4 \%$ consume bottled water.

The analyses of the results of this survey indicate that the modes of access to water are closely linked to household socioeconomic profile. However, Artelia (2017) survey conducted in Pointe-Noire reveals that $46 \%$ of households obtain water from a connection to the LCDE on their plot, compared to $45 \%$ who obtain water from neighbors, and $22 \%$ who obtain water from a private motorized borehole. In the economic literature, the use of piped water supply services is controversial in both theoretical and empirical work. On the theoretical level, two approaches are used, namely, the supply approach and the demand approach.

The first approach analyzes the supply of goods by determining the producer's behavior in the face of changes in prices and production factors and access to certain constraining factors (Pigou, 1928; Joskow, 2005; Rivard, 2008). The second explains that the quantities of a good demanded by a consumer are functions of prices and income (Marshall, 1890; Poi, 2002; Gaubert, 2008).

Empirically, there are two opposing views when analyzing the determinants of the use of piped water supply services. In the first, supported by Schleich and Hillenbrand (2009) and Nkengfack et al. (2017), the determinants of the mode of supply of piped water comprise socioeconomic factors. In contrast, the second view, advocated by Briand et al. (2009) and Porcher and Goumiri (2019), considers that the determinants are sociodemographic factors.

In light of the above factors and the findings for the city of Pointe-Noire, we ask the following question: What are the determinants of the use of piped water services in the city of Pointe-Noire? The objective of this article is to analyze the determinants of the use of piped water services. We support the hypothesis that income, level of education, and the activity of the head of household are among the determinants that influence household behavior regarding the use of piped water. This hypothesis builds on the work of Porcher and Goumiri (2019), Hounmenou (2014) and Briand et al. (2009), which explains household choices regarding the mode of piped water used.

In addition to the introduction and conclusion, this article is divided into three sections. The first discusses the literature, the second is the methodology and the third presents an analysis, interpretation and discussion of the results.

\section{The Economic Literature on the Determinants of the Use of the Water Supply Service}

The analysis of the modes of supply of piped water has given rise to abundant theoretical and empirical literature. From a theoretical point of view, the literature on the analysis of the determinants of the use of piped water supply services highlights two (2) types of theories, namely, supply theories and demand theories. 


\subsection{Theoretical Review}

As far as supply-side theories are concerned, the theoretical foundations of Condorcet, the paradox of the same name, the theories of neoclassicists such as Sax (1924) and Pigou (1928), and the theory of marginal utility are applied to the problem of the optimal determination of the supply of public goods. Following them, the development of prices was demonstrated by Hotelling (1938), and Boiteux (1949) in numerous reviews, which are the source of the Ramsey-Boiteux Rule. An upswell of renewed interest has led to a debate on various ways of pricing. For example, Hewitt (2000) developed party pricing.

However, Rivard (2008) believes that marginal cost pricing, which consists of applying the inverse elasticity rule, leads to the social optimum, as clarified by Joskow (2005). On the other hand, Eboue (1995) believes that average cost pricing ensures true pricing. Samuelson's (1954) theory of public goods characterizes the water supply service as a collective good and, more specifically, a local public good, characterized by non-exclusion and the absence of rivalry.

Similarly, the theory of the efficient supply of collective goods specifies that the existence of public goods is a decisive argument in favor of the existence of the state. In replacing the market, the state must show that it is more efficient than the market. The efficiency of state intervention in the provision of public goods can be measured by the Pareto optimum. According to liberal economic theory, the Pareto optimum (Pareto, 1906) requires that the marginal rate of transformation be equal to the sum of the marginal rates of substitution.

However, the classical approach to demand considers that the quantities demanded by a consumer are functions of prices and income. Marshall (1920), in his specific analytical framework, proved that this demanding relationship also expresses the prices that consumers are willing to pay for various quantities of goods. This dimension is omitted in contemporary developments of demand theory. The current assumptions regarding demand, including those that explain the accounting price system, make it possible to develop a theory of valuation that is perfectly general and forms a duality with the theory of demand. In the classical analysis of the classical approach to the demand side of the equation, the demand for piped water is initially treated as demand for goods whose production is independent of supply and whose elasticity is estimated to identify it. In this analytical framework, the household is considered a consumer that maximizes its utility under the constraint of income with an autonomous decision, according to Moschini and Moro (1993).

This approach is based on Lancaster's (1966) theory of consumer choice and supplemented by two additional approaches: the analysis of the complete system of household demand, which focuses on the economic determinants of household demand behavior, and the analysis of the sociological and cultural determinants of household adoption or choice (Browning \& Zupan, 2004). The household demand system approach aims to specify and estimate the determinants of household demand through the calculation of price and income elasticities. 
This effort is always situated within a supply perspective. Lancaster (1991) describes the passive nature of the good in the standard theory of consumer behavior (1966). The consumer behaves as a demander who seeks to consume as many goods as possible at the lowest possible price without considering the intrinsic characteristics of each good. Faced with the neutrality of the good consumed, Lancaster (1991) suggests a new approach based on three basic hypotheses: that the good itself does not have utility for the consumer, that it has properties and that it is these properties that determine the utility of the good. These assumptions form the basis of the basket analysis approach.

\subsection{Empirical Review}

A large number of empirical works have analyzed the determinants of the use of piped water supply services, with mixed results. The results of statistical studies by Arbués et al. (2004) and Schleich and Hillenbrand (2009) show that income is an important factor determining the amount of water consumed; in contrast are the studies by Hounmenou (2014) on the determinants of rural users of the public drinking water service in the commune of Allada (Benin). Using a logistical regression, the author reveals that distance is the only determinant that has a significant influence on rural populations' use of public water services, and its impact is negative. Other determinants, such as the price of water, the availability of a traditional source, the average number of people who obtain water from an equivalent water point and the weight of water among consumption expenses, also have a negative influence on rural populations' use of public water services. However, household income has a positive effect.

Furthermore, the results of the ANOVA tests of the determinants of users of the public water management service obtained by Porcher and Goumiri (2019) in France show that age is weakly and negatively correlated with the use of public services such as water. Socioprofessional category is not associated with greater satisfaction, except for water management. In the article published by Briand et al. (2009), the determinants of water supply choice are based on survey data for 301 Dakar households. The estimation of the bivariate probit model suggests that households' decision to obtain water from a private connection and/or from a standpipe are not independent. This paper provides new results regarding household water access in Africa. In particular, the authors show that factors such as gender and quality of service are important determinants of household choices.

Similarly, the results of the work by Nkengfack et al. (2017) in Cameroon using the classical time series linear regression model explain that the annual amount of investment and the urban population are determinants of the drinking water supply service. Gomez et al. (2016) examine access to drinking water in the commune of Banté in Benin, using a methodological approach based on documentary research and data collection through direct observation and interviews (direct and indirect). Their results show that payment for water service and preference are determinants of the use of public water service. Finally, Du- 
quesne (2012), in a study of the determinants of water consumption in Paris, uses the Prais-Winsten estimation method, which corresponds to ordinary least squares (OLS), finds that sociodemographic variables such as the number of dwellings, age, the size of the dwellings and the owners of the dwellings are determinants of drinking water consumption.

The results of this literature review allow us to observe the conformity of theoretical works with the analysis of empirical works regarding the determinants impacting the mode of running water supply chosen by households. However, the opinions of the authors diverge regarding the determinants that lead to the use of the supply mode. This divergence of opinion leads us to address this issue. The scarcity of research on this subject in the city of Pointe-Noire strengthens our choice of this focus.

Thus, the commune of Pointe-Noire constitutes a particularly interesting field with regard to the importance of the issue of piped water supply. Most of the work on the modes of supply of running water has used demographic and economic variables, theories of demand and econometric models such as: logistic regression (Hounmenou, 2014), the bivariate Probit (Briand et al., 2009), the Prais-Winsten estimation method which corresponds to Ordinary Least Squares (OLS) (Duquesne, 2012), the linear regression model of classical time series (Nkengfack et al., 2017) and the Anova tests (Porcher \& Goumiri, 2019). Few of the works have dealt with this topic with the multinomial logit model, the amount of the variable spent on water, the type of building materials and the supply theories. To this end, the use of the multinomial logit model, supply-side theories and the introduction of the amount of the variable spent on water and type of construction materials constitute a contribution to the review of the literature on the issue of piped water supply in developing countries in general and in the city of Pointe-Noire in particular.

\section{Methodology}

The first point of this subsection presents the methodology used, starting with the theoretical model selected and continuing to the specification of the variables considered.

\subsection{Theoretical Basis of the Unordered Multinomial Logit Model}

The theoretical basis of the unordered multinomial logit model is nothing more than the modeling of the behavior of producers according to several alternatives. Multinomial models are the most appropriate models for this purpose. Within the class of multinomial models, we distinguish between unordered multinomial models and ordered multinomial models. Households' choice among the different modes of supply of improved water is unordered because it is difficult to classify a priori the different strategies or combinations of strategies. Thus, the modeling that interests us here is so-called unordered modeling.

The multinomial probit model is used to account for the behavior of individ- 
uals choosing from a limited number of alternatives. According to Hausman (1980), the multinomial probit model is the most flexible for taking into account possible correlations between choices or between individuals, but in its most general form, this model requires very complex calculations to be carried out in practice as soon as the number of alternatives exceeds five.

The multinomial logit model was first introduced in the late 1960s by McFadden (1968) and Theil (1969). Additionally, the multinomial logit model has great flexibility and ease of use compared to the multinomial probit model of Hausman and McFadden (1984). Because of the advantages of this model, we opt for its use in this study. Note, in passing, that unordered multinomial models are, above all, models for describing individual choices in the presence of stochastic utility (Hurlin, 2003). Faced with several alternatives, the possibilities of making one choice or another are independent in the multinomial logit model. It is the independent logit model that interests us in this study because its utility function is a linear one for which the parameters differ according to the modalities and the explanatory variables vary only according to the individuals.

\subsection{Theoretical Model}

A household's choice of water supply mode depends in part on the context in which households make their choices. Indeed, the local context is considered to condition both the cost and the efficiency of the piped water supply. On the basis of econometric analysis, we highlight the influence of the local context on households' selection of different running water supply modes.

The estimates are performed for a single Congolese department. The regression model takes the following form: The estimation strategy is based on an econometric model that allows us to test the theoretical propositions formulated. The objective of the model, therefore, is to identify the determinants of a qualitative decision that identifies users' selection of a mode of supply of running water $i$ as opposed to the $k$ other possible modes. The dependent variable of the econometric model is therefore the probability of choosing one of the running water supply modes. Ultimately, it is a polyatomic variable that takes $n$ mutually exclusive terms for each mode of piped water supply $j$; that is to say that $1+\sum_{i=1}^{n} \operatorname{Pr}\left(M_{j}=i\right)=1, \forall j$, with $j=\{0,1,2\}$ and $i=\{0,1,2\}$. The regression model takes the following form:

$$
\operatorname{Pr}\left(M_{j}=i\right)=E\left(M_{j i} \mid Y_{j}, T_{j}\right)=Y_{j} \varphi_{i}+T_{j}
$$

Regarding the theoretical modeling presented above, the probability that household $j$ will choose piped water supply mode $i$ is therefore conditioned on the structural constraints of household $j\left(Y_{j}\right)$ and the socioeconomic characteristics observed in household $j\left(T_{j}\right) . w_{i}$ is an error term related to the unobserved variables. The parameters of the model $(\varphi, \alpha$ and $w)$ depend on the modalities of the dependent variable. Because the values taken by the dependent variable are unordered, we chose to estimate the model parameters using a multinomial logit model, the most commonly used estimation model for analyzing unordered 
multinomial choices (Sukami, 2021). The probability that household $j$ chooses mode $i$ rather than the $k$ other modes is then defined by the following formula:

$$
\operatorname{Pr}\left(M_{j}=i\right)=\frac{\exp \left(Y_{j} \varphi_{k}+T_{j} \alpha_{k}+w_{i}\right)}{1+\sum_{k=1}^{n-1} \exp \left(Y_{j} \varphi_{k}+T_{j} \alpha_{k}+w_{i}\right)}
$$

It is expressed in relation to a reference modality (here, mode 1), which corresponds to a mode of supply of a basic improved water source:

$$
\operatorname{Pr}\left(M_{j}=1\right)=\frac{1}{1+\sum_{k=1}^{n-1} \exp \left(Y_{j} \varphi_{k}+T_{j} \alpha_{k}+W_{k}\right)}
$$

The estimates are based on a sample of one (1) Congolese department, which was the subject of a survey on the organization of running water supply modes in the commune of Pointe-Noire.

\subsection{Source of Data and Presentation of Variables}

The data used in this article are from a household survey (ARTELA, 2017) conducted in Pointe-Noire. The selection of this data source is justified by the fact that it is directly related to questions regarding running water supply modes. Before conducting the actual econometric analysis, it was necessary to choose the variables that would be entered into each of the model's equations. To do this, we relied on the work of Sukami (2021), as well as various regressions and estimates that are not presented in this article.

\subsection{Independent Variables}

The important factors that affect the provision of piped water in most studies are income, age, education, gender and other variables. The analysis of these factors is presented below.

Age: Age is an important factor in decision-making regarding water supply patterns. The assumption is that older people are more mature and better able to assess the relationship between health and water issues. Consequently, they are more likely to use an appropriate water supply mode.

Education level and ownership status: are important for explaining household sourcing decisions (Madanat \& Humplick, 1993; Larson et al., 2006; Nauges \& Strand, 2007; Nauges \& Van Den Berg, 2009).

Household size: Both household size and structure are likely to influence household water supply choices. The number of members in the household and the person declared as the head of the household is considered in the analysis.

Gender: The presence of a female head of household may play an important role in the household's choices. Very often, the burden of fetching water falls on women and children, who often have to travel long distances, leaving less time for other activities such as domestic chores and income-generating activities.

Income: In choosing the mode of water supply, the amount of income reported by respondents is usually the interviewee's monthly income. However, if the service to be evaluated concerns the entire household, the income given 
should be that of all of the members of the family.

Weight of water (10 L bucket and $25 \mathrm{~L}$ can) used per day: This expresses the weight of water expenses among the weekly consumption expenses. It can be assumed that an increase in this weight is a disincentive to water consumption by the household.

Type of building materials used in the household's dwelling: This variable can qualify the standard of living of some households and their ability to pay for the water utility. Households that are built with a more durable type of material are more willing to pay for the piped water supply service.

Number of households on a plot: The number of households on a plot can influence the heads of household to choose a type of piped water service connection for the plot by mutual agreement.

Activity of the head of household: This is a very important variable for households as it allows consumers of public water services to make regarding the running water supply mode.

Cost of water: This indicates the purchase price of water. The units of measurement are $10 \mathrm{~L}$ buckets and $25 \mathrm{~L}$ cans. The expected sign of the variable is negative. In accordance with neoclassical theory, previous work converges on the negative impact of an increase in the price of water on water consumption.

\subsection{Descriptive Statistics of Variables}

Table 1 below presents the statistical data for the quantitative variables. The households in the sample have an average age of 49 years. The average number of people per household is 6 people; more precisely, each of the households in our sample includes 5.56 of the sample population. The households earn an average income of 332459 CFA francs.

Table 1. Descriptive statistics for quantitative variables.

\begin{tabular}{|c|c|c|c|c|c|}
\hline Variables & Mean & Min & $\operatorname{Max}$ & $\begin{array}{l}\text { Standard } \\
\text { deviation }\end{array}$ & Observation \\
\hline Age & 49.08935 & 20 & 83 & 12.05833 & 526 \\
\hline Household size & 5.5684 & 0 & 22 & 2.9783 & 526 \\
\hline Nbr of households on the plot & 2.8422 & 1 & 14 & 2.1165 & 526 \\
\hline $\begin{array}{l}\text { Amount spent per day on } \\
\text { spring water supply }\end{array}$ & 178.1483 & 0 & 4500 & 388.7755 & 526 \\
\hline $\begin{array}{l}\mathrm{Nbr} \text { of } \mathrm{S}(10 \mathrm{~L}) / \mathrm{d} \text { to/d } \\
\text { from alternative sources }\end{array}$ & 1.6425 & 0 & 30 & 4.0915 & 526 \\
\hline $\begin{array}{l}\text { Nbr of cans }(25 \mathrm{~L}) / \mathrm{d} \\
\text { from alternative sources }\end{array}$ & 4.0915 & 0 & 18 & 3.0892 & 526 \\
\hline Household income & 332,459 & 475 & $4,760,000$ & $310,891.8$ & 526 \\
\hline
\end{tabular}

Source: Authors, based on household survey data (ARTELA, 2017). 
The descriptive statistics of the explanatory variables retained for the econometric analysis show that there are more men (77.95\%) than women $(22.05 \%)$ in the sample. The type of construction materials used in the respondent's dwelling is included to examine the influence of this variable on payments for water supply services in the city of Pointe-Noire. $61.41 \%$ of households live in houses built of Aggelos. A total of 5.32\% of respondents live in dwellings made of uncooked bricks, and $37.07 \%$ live in houses built with planks/wood. It is also noted that $57.41 \%$ of households in the city of Pointe-Noire have a secondary education, while $26.43 \%$ of households have higher education. $13.12 \%$ have a primary education, and the proportion of households that have not attended school is $3.04 \%$. Regarding the socio-professional situation, $11.79 \%$ of households are retired, and $61.41 \%$ are self-employed. In addition, only $26.81 \%$ of households are employed. This can be explained by the fact that hiring in the public and private sectors is very low and households are obliged to work in the private sector.

Table 2 presents the characteristics of the dependent variables used in our multinomial logit model. According to this table, $56 \%$ of the households in our sample are connected to the LCDE (formerly the SNDE) as a source of improved water, while $35.5 \%$ obtain their water from neighbors, and $7.79 \%$ use a private connection to a motorized borehole in the city of Pointe-Noire.

\section{Presentation of the Multinomial Logit Model Results}

Table 3 presents the results of the estimation of the multinomial logit model for a sample of 526 users of the water supply service, and Table 4 and Table 5

Table 2. Descriptive statistics for qualitative variables.

\begin{tabular}{|c|c|c|c|}
\hline Variable & Modalities & Frequency & Proportion \\
\hline \multirow{4}{*}{ Level of education } & $0=$ Not in school & 16 & $3.04 \%$ \\
\hline & $1=$ Primary & 69 & $13.12 \%$ \\
\hline & $2=$ Secondary & 302 & $57.41 \%$ \\
\hline & $3=$ Superior & 139 & $26.43 \%$ \\
\hline \multirow{2}{*}{ Gender } & $1=\operatorname{Man}$ & 410 & $77.95 \%$ \\
\hline & $2=$ Woman & 116 & $22.05 \%$ \\
\hline \multirow{3}{*}{ Building material of dwelling } & $0=$ Agglos & 303 & $57.60 \%$ \\
\hline & $1=$ Unbaked bricks & 28 & $5.32 \%$ \\
\hline & 2 = Planks $/$ wood & 195 & $37.07 \%$ \\
\hline \multirow{3}{*}{$\begin{array}{l}\text { Activity of the head } \\
\text { of the household }\end{array}$} & $0=$ Liberal Professional & 323 & $61.41 \%$ \\
\hline & $1=$ Employed & 141 & $26.81 \%$ \\
\hline & $2=$ Retired & 62 & $11.79 \%$ \\
\hline
\end{tabular}

Source: Authors, based on household survey (ARTELA, 2017). 
Table 3. Descriptive statistics of the dependent variables included in the model.

\begin{tabular}{ccccc}
\hline Variable & Modalities & Frequency & Prop. & Cum. \\
\hline Y1 = 0 & LCDE (Ex SNDE) & 298 & $56.65 \%$ & 56.65 \\
Y1 = 1 & Neighbors & 187 & $35.55 \%$ & 92.21 \\
Y1 = 2 & Private motorized borehole & 41 & $7.79 \%$ & 100.00 \\
\hline
\end{tabular}

Source: Authors, based on household survey (ARTELA, 2017).

Table 4. Model estimation results.

\begin{tabular}{|c|c|c|}
\hline Variable & Model 2 & Model 3 \\
\hline Age & $\begin{array}{l}-0.023 \\
(0.022)\end{array}$ & $\begin{array}{l}-0.016 \\
(0.025)\end{array}$ \\
\hline Gender (male) & Ref & Ref \\
\hline Female & $\begin{array}{c}-0.859^{*} \\
(0.477)\end{array}$ & $\begin{array}{c}0.103 \\
(0.576)\end{array}$ \\
\hline Household size & $\begin{array}{c}-0.184^{* *} \\
(0.077)\end{array}$ & $\begin{array}{c}-0.215^{\star *} \\
(0.091)\end{array}$ \\
\hline Nbr of households on plot & $\begin{array}{l}-0.210 \\
(0.142)\end{array}$ & $\begin{array}{c}-0.341^{* *} \\
(0.162)\end{array}$ \\
\hline Nbr of $S(10 \mathrm{~L}) / \mathrm{d}$ at/d from alternative sources & $\begin{array}{c}0.616^{* * *} \\
(0.143)\end{array}$ & $\begin{array}{c}0.481^{* * *} \\
(0.151)\end{array}$ \\
\hline Nbr of cans $(25 \mathrm{~L}) / \mathrm{d}$ from alternative sources & $\begin{array}{c}1.425^{\star * *} \\
(0.294)\end{array}$ & $\begin{array}{c}1.555^{* * *} \\
(0.314)\end{array}$ \\
\hline \multicolumn{3}{|l|}{ Level of education } \\
\hline Not in school & Ref & Ref \\
\hline Primary & $\begin{array}{l}-1.134 \\
(0.744)\end{array}$ & $\begin{array}{l}-1.364 \\
(0.945)\end{array}$ \\
\hline Secondary & $\begin{array}{c}-2.295^{\star * *} \\
(0.730)\end{array}$ & $\begin{array}{c}-2.118^{* *} \\
(0.910)\end{array}$ \\
\hline Higher & $\begin{array}{c}-2.992^{\star * *} \\
(0.818)\end{array}$ & $\begin{array}{c}-3.414^{* * *} \\
(1.184)\end{array}$ \\
\hline
\end{tabular}

Activity of the head of the household

$\begin{array}{ccc}\text { Liberal profession } & \text { Ref } & \text { Ref } \\ \text { Employee } & -0.564 & -0.688 \\ & (0.484) & (0.635) \\ \text { Retired } & -1.065 & -0.728 \\ & (0.887) & (0.951) \\ \text { Household income } & -2.73 \mathrm{e}-06^{*} & -6.21 \mathrm{e}-07 \\ & (1.63 \mathrm{e}-06) & (9.35 \mathrm{e}-07)\end{array}$

Building material of dwelling 


\section{Continued}

\begin{tabular}{ccc}
\hline Unbaked brick & 0.550 & $-11.333^{* * *}$ \\
Boards/wood & $(0.868)$ & $(0.711)$ \\
& $1.187^{* * *}$ & $1.202^{* *}$ \\
Amount per day spent on spring water & $(0.354)$ & $(0.466)$ \\
& $-0.002^{* * *}$ & $-0.003^{* * *}$ \\
Constant & $(0.000)$ & $(0.001)$ \\
& $2.400^{*}$ & 0.086 \\
& $(1.424)$ & $(1.697)$
\end{tabular}

$\mathrm{Nbr}=526$; Wald chi2 $(30)=2311.78$; Prob $>$ chi $2=0.0000$; pseudo-R2 $=0.6024 ; \log$ pseudolikelihood $=-185.83679$

${ }^{\star} p<0.1 ;{ }^{* *} p<0.05 ;{ }^{* *} p<0.01$. NB: Model $1=(\mathrm{LCDE})$; Model $2=$ (neighbors) and Model 3 = (private motorized borehole).

Table 5. Results of marginal effects.

\begin{tabular}{|c|c|c|c|}
\hline \multirow{2}{*}{ Variables } & Model 1 & Model 2 & Model 3 \\
\hline & $d y / d x$ & $d y / d x$ & $d y / d x$ \\
\hline Age & $\begin{array}{c}0.005 \\
(0.005)\end{array}$ & $\begin{array}{l}-0.005 \\
(0.005)\end{array}$ & $\begin{array}{l}-0.000 \\
(0.000)\end{array}$ \\
\hline Sex (male) & Ref & Ref & Ref \\
\hline Female & $\begin{array}{c}0.181^{*} \\
(0.107)\end{array}$ & $\begin{array}{c}-0.202^{* *} \\
(0.097)\end{array}$ & $\begin{array}{c}0.020 \\
(0.024)\end{array}$ \\
\hline Household size & $\begin{array}{l}0.046^{* *} \\
(0.019)\end{array}$ & $\begin{array}{c}-0.041^{* *} \\
(0.018)\end{array}$ & $\begin{array}{c}-0.005^{*} \\
(0.003)\end{array}$ \\
\hline Nbr of households on the plot & $\begin{array}{c}0.055 \\
(0,035)\end{array}$ & $\begin{array}{l}-0.045 \\
(0.032)\end{array}$ & $\begin{array}{c}-0.009^{* *} \\
(0.004)\end{array}$ \\
\hline Nbr of buckets $(10 \mathrm{~L}) /$ day in dry areas & $\begin{array}{c}-0.150^{* * *} \\
(0.036)\end{array}$ & $\begin{array}{c}0.142^{* * *} \\
(0.033)\end{array}$ & $\begin{array}{c}0.008^{*} \\
(0.004)\end{array}$ \\
\hline Nbr of $25 \mathrm{~L}$ cans/day in dry areas & $\begin{array}{c}-0.358^{* * *} \\
(0.076)\end{array}$ & $\begin{array}{c}0.322 \\
(0.069)\end{array}$ & $\begin{array}{c}0.036^{* * *} \\
(0.011)\end{array}$ \\
\hline \multicolumn{4}{|l|}{ Level of education } \\
\hline No schooling & Ref & Ref & Ref \\
\hline Primary & $\begin{array}{c}0.160^{*} \\
(0.089)\end{array}$ & $\begin{array}{l}-0.132 \\
(0.118)\end{array}$ & $\begin{array}{l}-0.027 \\
(0.066)\end{array}$ \\
\hline Secondary & $\begin{array}{c}0.420^{* * *} \\
(0.085)\end{array}$ & $\begin{array}{c}-0.389^{* * *} \\
(0.113)\end{array}$ & $\begin{array}{l}-0.030 \\
(0.065)\end{array}$ \\
\hline Higher & $\begin{array}{c}0.595^{* * *} \\
(0.109)\end{array}$ & $\begin{array}{c}-0.532^{* * *} \\
(0.131)\end{array}$ & $\begin{array}{l}-0.063 \\
(0.064)\end{array}$ \\
\hline
\end{tabular}

Activity of the head of the household

$\begin{array}{cccc}\text { Liberal profession } & \text { Ref } & \text { Ref } & \text { Ref } \\ \text { Employee } & 0.142 & -0.126 & -0.016 \\ & (0.117) & (0.110) & (0.0020)\end{array}$




\section{Continued}

\begin{tabular}{cccc}
\hline Retired & 0.246 & -0.234 & -0.012 \\
& $(0.187)$ & $(0.175)$ & $(0.029)$ \\
Household income & $6.35 \mathrm{e}-07^{*}$ & $-6.61 \mathrm{e}-07^{*}$ & $2.59 \mathrm{e}-08$ \\
& $(3.79 \mathrm{e}-07)$ & $(3.89 \mathrm{e}-07)$ & $(3.58 \mathrm{e}-08)$ \\
Building material used for dwelling & & & \\
Sheet metal & Ref & Ref & Ref \\
Unbaked brick & -0.094 & 0.153 & $-0.059^{* *}$ \\
& $(0.214)$ & $(0.216)$ & $(0.023)$ \\
Boards/wood & $-0.287^{* * *}$ & $0.242^{* * *}$ & 0.045 \\
& $(0.076)$ & $(0.074)$ & $(0.032)$ \\
Amount per day spent on spring water & $0.000^{* * *}$ & $-0.000^{* * *}$ & $-0.000^{* *}$ \\
& $(0.000)$ & $(0.000)$ & $(0.000)$ \\
\hline
\end{tabular}

${ }^{\star} p<0.1 ;{ }^{* *} p<0.05 ;{ }^{* *} p<0.01$.

present the marginal effects of the explanatory variables on the dependent variable. The dependent variable is a polyatomic variable indicating the use or nonuse of the sources of running water (LCDE, neighbors and private motorized borehole). Overall, the model is statistically validated. Indeed, its chi-square $\left(\chi^{2}\right)$ (2311.78) is significant at $1 \%$. The pseudo-R2 value $(0.6024)$ is satisfactory and approximates the proportions of the variance explained by the model.

\section{Interpretation and Discussion of Results}

The analysis of the determinants of the use of the piped water supply service in the city of Pointe-Noire is based on three types of determinants: socioeconomic, environmental and economic.

\section{Explanatory determinants related to socio-economic aspects}

The observations of the study show that the marginal effects of the income variable in the first two models are significant and have a positive impact on the supply of running water in the LCDE and a negative impact on the neighbors. Indeed, in the empirical literature, our results confirm the work of Hounmenou (2014), which shows a positive relationship between income and water connection at LCDE, and that of Schleich and Hillenbrand (2009); Arbués et al. (2004) reveals that income is an important factor that determines the quantity of water for consumption. From a theoretical point of view, one theory is retained: the Lancaster (1966) theory. This theory is based on the maximization of the utility that a consumer can obtain by consuming a good or service under income constraints. It establishes the relationship between household income and the provision of piped water. The amount determinant is significant at the $1 \%$ threshold, followed by a positive impact on the connection to the LCDE. In contrast, Models 2 and 3 reduce the probability of obtaining water from neighbors by $1 \%$ and from a motorized private well by $5 \%$. In the empirical literature, these results contradict those of Hounmenou (2014), who stated that the price of water also 
has a negative but not significant influence on rural populations of public water services.

\section{Explanatory determinants related to sociodemographic factors}

The results of the marginal effects of the education level variable are significant at the $1 \%, 5 \%$ and $10 \%$ thresholds. This variable has a positive impact on the use of running water from the LCDE. In contrast, in the second model, it reduces the probability of obtaining water from neighbors by $1 \%$. The literature on corrective state intervention through control, administration or taxation, as advocated in Pigou's (1928) neoclassical approach, indicates that a more educated household is more aware of the health benefits associated with the consumption of piped water (i.e., an LCDE connection).

\section{Explanatory determinants related to environmental factors}

The variable type of building materials used in the household's dwelling reduces the probability that a household will use a connection to the LCDE by $1 \%$ and reduces the probability of using a motorized private borehole by $5 \%$. It increases the probability that a household will obtain water from a neighbor by $1 \%$. This result, which is new for Pointe-Noire, is consistent with the literature analyzing the determinants of the use of piped water supply services. The marginal effects of the gender variable show that being a woman increases the probability of obtaining water from the LCDE by $10 \%$ and decreases the probability of obtaining water from neighbors by $5 \%$; furthermore, these two supply methods are used jointly when the quality of private connections is not satisfactory and when the household does not have access to a well or other sources. These results, which are new for Pointe-Noire, appear to be original.

The quantity of water variable is significant and has a positive impact on the choice of a private motorized borehole as the water supply. These results support literature review on both the theoretical and empirical level. On the empirical side, they corroborate the work of Hounmenou (2014), which reveals that the weight of water among consumption expenditures has a negative influence for rural populations. At the theoretical level, the results support the approach of the theory of demands for goods (Marshall, 1890; Poi, 2002; Gaubert, 2008), which explains the relationship between prices and quantities of goods. The household size determinant has a positive effect on the selection of the LCDE as the water source and reflects the value that the household places on this connection. This result, which is new for Pointe-Noire, is consistent with the literature on the determinants of use of the public water supply service.

\section{Conclusion}

The main results obtained allow us to situate this analysis in two ways. First, the selection of the LCDE as the water source in the commune of Pointe-Noire is fundamentally linked to the following variables: household income, level of education, amount spent per day on water, gender (female), household size and quantity of water used. Together, these variables determine the decision to con- 
nect to the LCDE.

Second, the use of neighbors as a source of water is related to the type of building materials used for the household's dwelling and the quantity of water used, while the use of a private motorized borehole as a source of water supply is related to the quantity of water used. Based on these results, this article sheds light on factors that determine the choice of running water supply source in the city of Pointe-Noire and confirms the hypothesis of this article. This hypothesis considers that income and level of education are among the factors that influence the behavior of Congolese households in selecting the sources of their running water supply.

Beyond these different contributions obtained in terms of results in this work, it should be noted that this article has a number of limitations: The database used to analyze the determinants of the use of the piped water supply service is limited to the commune of Pointe-Noire. The nature of the data at our disposal does not allow for the same analyses elsewhere.

Thus, at the end of our work, we can propose the following solutions to the problem of the water supply in Pointe-Noire. It is necessary to increase investment in this sector to encourage consumers to pay the real cost of this resource because of its socio-economic importance; to revalue the price per $\mathrm{m} 3$ of water or increase users' contribution to avoid wasting this resource; to control the management and operation of the organization in charge of distribution because subsidies can lead to poor management and encourage the involvement of private actors in this sector.

\section{Conflicts of Interest}

The authors declare no conflicts of interest regarding the publication of this paper.

\section{References}

Arbués, F., Barberan, R., \& Villanua, I. (2004). Price Impact on Urban Residential Water Demand: A Dynamic Panel Data Approach. Water Resources Research, 40, W11402. https://doi.org/10.1029/2004WR003092

Artelia (2017). L'enquête réalisée auprès des ménages dans les 6 arrondissements de Pointe-Noire Lumumba, Mvoumvou, Tié-tié, Loandjili, Mongo-Mpoukou et Ngoyo.

Boiteux, M. (1949). La tarification des demandes en pointe: Application de la théorie de la vente au cout marginal. Revue Générale de l'Electricité, 58, 321-340.

Briand, A. et al. (2009). Les Déterminants Du Choix D’approvisionnement En Eau Des Ménages De Dakar. Revue D'économie Du Développement, 17, 83-108. https://doi.org/10.3917/edd.233.0083

Browning, E., \& Zupan, M. (2004). Microeconomic Theory and Applications (8th ed.). Wiley.

Duquesne, J. (2012). Etude des déterminants de la consommation d'eau à Paris.

Eboue, C. (1995). Les monopoles naturels électriques en Afrique: Une évaluation. Editions AUPELF-UREF, John Libbey Eurotext. 
Gaubert, P. (2008). Le schéma classique de la demande. http://patrice.f.gaubert.pagesperso-orange.fr/microapp/sup1.pdf

Gomez, C. et al. (2016). Déterminants de l'accès à l'eau potable dans la Commune de Bantè ... (EDUCI). 2016 Revue de Géographie Tropicale et d'Environnement, No. 2.

Hausman, J. (1980). Les modèles probit de choix qualitatif. Cahiers du Séminaire d'Économétrie@ 1980 L'INSEE/GENES. http://www.jstor.org/stable

Hausman, J., \& McFadden, D. (1984). Specification Tests for the Multinomial Logit. Econometrica, 52, 1219-1240. https://doi.org/10.2307/1910997

Hewitt, J. A. (2000). An Investigation into the Reasons Why Water Utilities Choose Particular Residential Rate Structures. In A. Dinar (Ed.), The Political Economy of Water Pricing Reforms (pp. 259-277). Oxford University Press.

Hotelling, H. (1938). The General Welfare in Relation to Problems of Taxation and of Railway and Utility Rates. Econometrica, 6, 242-269. https://doi.org/10.2307/1907054

Hounmenou, B. (2014). Satisfaction Des Populations Du Service Public De L'eau Dans La Commune D’allada (Bénin). Revue D'économie Théorique et Appliquée, 4, 43-54.

Hurlin, C. (2003). Cours d'économétrie des Variables Qualitatives Chapitre 2: Modèles Logit Multinomiaux Ordonnées et non Ordonnés. Université d'Orléans.

Joskow, P. L. (2005). Supply Security in Competitive Electricity and Natural Gas Markets.

Lancaster, K. (1991). Modem Consumer Theory. Edward Elgar.

Lancaster, K. J. (1966). A New Approach to Consumer Theory. Journal of Political Economy, 74, 132-157. https://doi.org/10.1086/259131

Larson, B., Minten, B., \& Razafindralambo, R. (2006). Unravelling the Linkages between the Millennium Development Goals for Poverty, Education, Access to Water and Household Water Use in Developing Countries: Evidence from Madagascar. Journal Of Development Studies, 42, 22-40. https://doi.org/10.1080/00220380500356258

Madanat, S., \& Humplick, F. (1993). A Model of Household Choice of Water Supply Systems in Developing Countries. Water Resources Research, 29, 1353-1358. https://doi.org/10.1029/93WR00126

Marshall, A. (1890). Principles of Economics. MacMillan, Eighth Edition 1920, Reprint 1982.

Marshall, A. (1920). Principles of Economics. Huitième Edition, Macmillan, 1920. Réimpression, Macmillan, 1964.

McFadden, D. (1968). The Revealed Preference of a Public Bureaucracy. Dept. of Economics, University of California.

MICS (2014-2015). Enquête par grappes à indicateurs multiples (MICS5 CONGO 20142015).

Moschini, G., \& Moro, D. (1993). A Food Demand System for Canada, Agriculture Canada (pp. 3-118). Technical Report 1/93, Agriculture Canada, Policy Branch.

Nauges, C., \& Strand, J. (2007). Estimation of Non-Tap Water Demand in Central American Cities. Resource and Energy Economics, 29, 165-182. https://doi.org/10.1016/j.reseneeco.2006.05.002

Nauges, C., \& Van Den Berg, C. (2009). Demand for Piped And Non-Piped Water Supply Services: Evidence from Southwest Sri Lanka. Environmental and Resource Economics, 42, 535-549. https://doi.org/10.1007/s10640-008-9222-Z

Nkengfack, H., Noubissi Domguia, E., \& Kamajou, F. (2017). Analyse Des Determinants De L'offre De L'eau Potable Au Cameroun. Hal-01510111.

Pareto, V. (1906). Manuale d'economia politica, Milano: Società editrice libraria (1ère 
édition française). Giard et Brière 1909, réédition in Euvres complètes de Vilfredo Pareto, Droz, 1966.

Pigou, A. C. (1928). A Study of Public Finance. MacMillan.

Poi, P. B. (2002). Demand System Estimation. The Stata Journal, 2, 403-410. https://doi.org/10.1177/1536867X0200200406

Porcher, S., \& Goumiri, A. (2019). La Satisfaction Des Usagers Des Services Publics Locaux: Une Etude Sur Les 10 plus Grandes Villes Françaises. Halshs-02408525.

Rivard, G. (2008). La structure tarifaire d'Hydro-Quebec, mémoire de maîtrise, UQAM.

Samuelson, P. A. (1954). The Pure Theory of Public Expenditure. Review of Economics and Statistics, 36, 387-389. https://doi.org/10.2307/1925895

Sax, E. (1924). Die Wertungstheorie der Steuer. Zeitschrift für Volkswirth-schaft und Sozialpolitik, 4, 191-240.

Schleich, J., \& Hillenbrand, T. (2009). Determinants of Residential Water Demand in Germany. Ecological Economics, 68, 1756-1769. https://doi.org/10.1016/j.ecolecon.2008.11.012

Sukami, E. (2021). Analyse économique de la gestion des déchets solides ménagers, en République du Congo Brazzaville: Cas de l'Enlèvement des déchets solides ménagers.

Theil, H. (1969). A Multinomial Extension of the Linear Logit Model. International Economic Review, 10, 251-259. https://doi.org/10.2307/2525642 